\title{
Peningkatan penerimaan diri pasien skizofrenia melalui Rational Emotif Behavior Therapy
}

$\Phi$ PROCEDIA Studi Kasus dan Intervensi Psikologi p-ISSN 2302-1462; e-ISSN 2722-7669 ejournal.umm.ac.id/index.php/procedia 2021, Vol 9(2):76-82

DOI:10.22219/procedia.v9i2.16298

(C) The Author(s) 2021

(1)(3) 4.0 International license

\author{
Aldila Putri Karindra ${ }^{1}$
}

\begin{abstract}
Delusions and irrational thoughts often appear in schizophrenic patients. Can those negative thoughts be reduced to them? Rational Emotive Behavior Therapy (REBT) is designed to help overcome the problems of negative thinking in schizophrenia. The assessment was carried out using interviews, observation and several psychological tests with the results of the dominance of negative feelings and low self-acceptance. The intervention aims to break irrational beliefs and increase self-acceptance through REBT techniques. The results of the intervention show that the client can see things from a different perspective in order to generate new, more rational thoughts so as to increase the client's acceptance of himself, others, and the environment.
\end{abstract}

\section{Keywords}

Self-acceptance, Rational Emotive Behavior Therapy, schizophrenia

\section{Pendahuluan}

Skizofrenia merupakan penyakit yang memiliki karakteristik adanya gangguan dalam proses berpikir, emosi dan perilaku. Seperti, gangguan proses pikir dimana terdapat ide-ide yang tidak logis dan tidak koheren satu dengan yang lainnya, persepsi dan atensi yang salah, kurang dalam emosi dan ekspresi, atau menunjukkan ketidaksesuaian ekspresi emosi serta gangguan dalam pergerakan dan perilaku (Davison, 2000). Gangguan skizofrenia adalah sekelompok reaksi psikotik yang mempengaruhi area fungsi individu, termasuk berpikir dan berkomunikasi, menerima, dan menginterprestasikan realitas, merasakan dan menunjukkan emosi, dan beperilaku dengan sikap yang dapat diterima secara sosial. Prevalensi gangguan ini kurang dari satu persen (American Psychiatric Association, 2013), namun memiliki tingkat relapse (kekambuhan) dan rehospitalization (masuk rumah sakit kembali) sebesar 60\% (Pitschel-Waltz, 2004).

Gejala skizofrenia secara garis besar dapat di bagi dalam dua kelompok, yaitu gejala aktif dan gejala negatif. Gejala aktif berupa delusi, halusinasi, kekacauan pikiran, gaduh gelisah dan perilaku aneh atau bermusuhan. Gejala negatif adalah alam perasaan (afek) tumpul atau mendatar, menarik diri atau isolasi diri dari pergaulan, 'miskin' kontak emosional (pendiam, sulit diajak bicara), pasif, apatis atau acuh tak acuh, sulit berpikir abstrak dan kehilangan dorongan kehendak atau inisiatif (Davison, 2000).

Skizofrenia dapat ditemukan pada semua kelompok masyarakat dan di berbagai daerah. Insiden dan tingkat prevalensi sepanjang hidup secara kasar hampir sama di seluruh dunia. Gangguan ini mengenai hampir 1\% populasi dewasa dan biasanya onsetnya pada usia remaja akhir atau awal masa dewasa. Pada laki-laki biasanya gangguan ini mulai pada usia lebih muda yaitu 15-25 tahun sedangkan pada perempuan lebih lambat yaitu sekitar 25-35 tahun. Insiden skizofrenia lebih tinggi pada laki-laki daripada perempuan dan lebih besar di daerah urban dibandingkan daerah rural (Davison, 2000).

Skizofrenia menyebabkan kerusakan serius pada aspek sosial, kognitif, afektif, dan keberfungsian sehari-hari (Halgin \& Withbourne, 2011). Dua cara yang paling ampuh dalam menangani gangguan skizofrenia dan gangguan jiwa lainnya adalah farmakoterapi dan psikoterapi, yang dalam kebanyakan kasus pasien akan sangat diuntungkan dengan adanya kedua kombinasi tersebut (Thome, 2015). Farmakoterapi efektif untuk mengatasi gejala aktif skizofrenia dan mengurangi kerentanan terhadap kambuh namun hal tersebut tidak mengatasi masalah residual defisit dalam hal kognitif dan sosial yang dapat diatasi melalui psikoterapi, salah satunya dengan pendekatan kognitif (Alford \& Beck, 1994).

Masalah residual defisit dalam hal kognitif dan sosial ini dialami oleh klien. Klien mengalami gangguan skizofrenia sejak usia 23 tahun dan telah mengalami 5 kali kambuh. Klien berulangkali kambuh karena memiliki irrational

${ }^{1}$ Rumah Sakit Umum Ulin, Banjarmasin

Korespondensi:

Aldila Putri Karindra, Rumah Sakit Umum Ulin, Banjarmasin, Kalimantan Selatan, Indonesia

Email: dilaputrimance@gmail.coml.com 
belief yang dikembangkannya sejak kecil sehingga membuatnya terkungkung pada satu pemikiran tanpa dapat melihat kemungkinan lain yang lebih rasional. Irrational belief dapat menjadi sesuatu yang patologis apabila menyebabkan beberapa disfungsi seperti yang dialami oleh klien (Sakakibara, 2016). Klien menjadi pribadi yang banyak menuntut bahwa segala sesuatunya berlaku suatu ke-harus-an dan apabila tidak maka klien akan memberikan label negatif yang berujung pada perilaku maladptif seperti menarik diri dan tidak mampu menerima dirinya tanpa syarat.

Irrational belief atau keyakinan yang irasional adalah keyakinan yang tidak masuk akal, kaku dan tidak konsisten dengan realitas sedangkan keyakinan rasional adalah keyakinan yang logis, fleksibel, dan konsisten dengan realitas. Dominasi keyakinan irasional mengakibatkan, orang memperoleh emosi yang tidak sehat, perilaku disfungsional dan gangguan psikologis. Dengan mematahkan keyakinan irrasional, orang dapat mengembangkan cara berpikir yang lebih rasional dan realistis sehingga akan menghasilkan penerimaan yang lebih besar terhadap diri sendiri dan orang lain. Penerimaan diri berarti menerima diri tanpa syarat terlepas dari apakah seseorang berperilaku kompeten atau benar dan apakah orang lain cenderung untuk menyatakan persetujuan atau rasa hormat (Dryden \& Neenan, 2004).

Seperti yang dialami oleh klien, dimana klien berpikiran bahwa dalam segala sesuatunya dalam hidup adanya keharusan absolutistik, meyakini bahwa bahwa hal tertentu harus terjadi atau tidak boleh terjadi, dan bahwa pada kondisi tertentu (misalnya kesuksesan, cinta atau persetujuan) merupakan kebutuhan mutlak. Penuntutan menyiratkan pada hukum alam semesta yang harus dipatuhi sehingga intervensi REBT diperlukan untuk mengatasi hal tersebut (Froggatt, 2005).

REBT dalam penelitian sebelumnya diketahui sebagai teknik yang mampu mengubah irrational belief dan menghasilkan pemikiran baru yang lebih rasional sehingga mampu meningkatkan penerimaan diri pada klien (Cunningham \& Turner, 2016). Selain intervensi pada klien diperlukan pula penanganan yang komprehensif dengan melibatkan keluarga dengan memberikan psikoedukasi untuk membantu klien mempertahankan keadaan optimumnya dan mencegah kekambuhan (Pitschel-Waltz, 2004).

\section{Metode Asesmen}

Asesmen dilakukan untuk penegakan diagnosa yang dilakukan melalui serangkaian metode antara lain wawancara, observasi dan tes psikologi. Wawancara dilakukan terhadap klien dan juga keluarga untuk memperoleh informasi lebih mendalam tentang riwayat permasalahan yang dialami klien. Observasi dilakukan untuk pemeriksaan status mental klien dan untuk memperoleh informasi perilaku dan aktivitas klien selama di rumah sakit.
Sementara tes psikologis digunakan untuk memperoleh informasi yang lebih mendalam yang tidak disadari klien/ tidak mampu diungkapkannya secara sadar. Tes psikologi yang digunakan mencakup tes kepribadian yaitu tes grafis (BAUM, DAP dan HTP), WARTEGG, SSCT dan TAT. Tes grafis dan wartegg diperlukan untuk mengetahui kepribadian klien secara lebih mendalam. Tes TAT untuk mengetahui kebutuhan dan juga tekanan yang klien alami. Sedang SSCT digunakan untuk mengetahui sikap klien terhadap orang lain atau lingkungan. Asesmen juga melibatkan tes inteligensi menggunakan Wescler Adult Intelligence Scale (WAIS) untuk mengetahui kapasitas intelektual serta gejala klinis yang mungkin terungkap.

\section{Presentasi Kasus}

Klien seorang perempuan berusia 43 tahun merupakan anak kedua dari lima bersaudara, tinggal di Pasuruan. Klien memiliki tubuh dengan tinggi sekitar $145 \mathrm{~cm}$ dan berat badan sekitar $60 \mathrm{~kg}$, memiliki rambut lurus yang dipotong pendek sebahu, terdapat 2 bekas luka parut di lutut kanan dan satu gigi seri yang patah akibat kecelakaan. Penampilan klien cukup bersih dan terawat, tidak berbau, memiliki kulit sawo matang dengan kulit yang kering terutama pada bagian kaki dengan tumit yang pecahpecah dan berwarna kehitaman. Wajah klien nampak sesuai dengan umurnya dengan beberapa bekas jerawat. Klien merupakan individu yang serba ingin tahu, namun kurang dapat menentukan tujuan dan mengambil keputusan. Memiliki keinginan yang besar dan tinggi namun tidak diimbangi dengan vitalitas untuk mengesekusi.

Klien dibawa ke RSJ karena marah-marah yang tidak terkendali pada anak dan suaminya, bahkan sampai memukuli suaminya. Klien mensobek-sobek kertas ataupun buku-buku yang ada di dalam rumah. Seringkali menyatakan ingin pergi kerumah temannya namun kerapkali ditemukan dipinggir jalan. Klien mengeluhkan mendengar bisikan-bisikan yang berupa ajakan untuk keluar rumah yang diturutinya namun mendapatkan hasil nihil dan kembali masuk kedalam rumah ataupun komentar-komentar tentang apa yang sedang dilakukannya.

Berdasarkan hasil wawancara yang telah dilakukan, klien memiliki tingkat intelegensi yang cukup baik dengan pengetahuan umum yang cukup luas. Hal tersebut dikuatkan dari pengakuan klien yang menyatakan bahwa dirinya sudah dapat membaca sejak usia lima tahun dan berhasil menjadi murid terpandai saat SD dan meraih juara umum serta meraih NUN tertinggi saat SMA serta hasil tes WAIS yang menunjukkan IQ verbal klien berada pada kategori rata-rata atas.

Ketika duduk di bangku SMP klien memiliki pengalaman yang tidak menyenangkan yaitu tidak lulus dalam seleksi olimpiade matematika, hal ini menyebabkan klien mengevalusi dan menginterpretasi keadaan dirinya dan timbul suatu reaksi emosi dimana klien merasa tidak mampu, merasa tidak berharga dan merasa tidak 
dapat memenuhi harapan orangtuanya. Klien mengevaluasi dirinya terus menerus dan secara tidak disadarinya, ia memberikan label yang negatif dan tidak rasional pada dirinya sendiri. Setelah itu muncul hambatan-hambatan perilaku seperti menurunnya prestasi di sekolah saat SMP yang disebabkan karena label negatif yang disematkan klien pada dirinya sendiri, yaitu tidak kompeten.

Klien dengan gangguan psikotik biasanya berasal dari keluarga yang memiliki disfungsi pada beberapa aspeknya. Perilaku keluarga yang patologis secara signifikan akan meningkatkan stres emosional yang harus dihadapi oleh klien psikotik. Adapun perilaku patologis tersebut seperti adanya tuntutan yang terlalu tinggi dari orangtuanya, sementara anak sebenarnya tidak memiliki kemampuan sebagaimana yang diharapkan oleh orangtuanya. Klien menyatakan dirinya diharuskan untuk selalu belajar dan mendapatkan prestasi yang baik disekolah. Klien dimasukkan ke dalam sekolah akselerasi dan bahkan saat kuliah, klien masuk pada jurusan yang dipilihkan oleh Ayahnya yang tidak sesuai dengan keinginan, minat dan bakat klien.

Hal tersebut sesuai dengan hasil tes grafis dan SSCT yang menunjukkan adanya kebutuhan kasih sayang dari Ayah yang tidak didapatkan oleh klien. Klien merasa ayahnya terlalu sibuk bekerja hingga kurang memperhatikan perkembangan anaknya. Klien berharap seandainya Ayahnya bisa lebih bijaksana untuk membagi waktu antara pekerjaan dan keluarga. Untuk kehidupan keluarga, klien merasa masa kecilnya bahagia sebagaimana keluarga lainnya. Namun dengan berjalannya waktu, klien merasa keluarganya memperlakukan klien seperti seseorang yang hanya mengganggu hidup mereka dan merasa seperti keluarga yang broken home. Pemikiran tersebut keluar saat klien beranjak dewasa, dimana klien mulai mengalami beberapa kegagalan dan mengembangkan keyakinan yang tidak rasional yang membuatnya semakin mendapatkan konsekuensi maladaptif yang berujung pada gejala patologis.

Sekalipun klien mampu memperoleh nilai NUN tertinggi tidak menjamin klien untuk bisa masuk ke PTN yang diinginkan. Klien gagal masuk ke PTN pilihannya, yaitu teknik kimia. Sehingga membuat klien kembali mengevaluasi keadaan dirinya dan muncul evaluasi negatif terhadap dirinya. Klien kembali merasa kurang kompeten. Perasaan kurang kompeten tersebut membuatnya tidak percaya diri untuk mendaftar kembali seleksi masuk PTN pada jurusan yang dia inginkan. Satu tahun kemuadian klien kembali mendaftar ulang seleksi masuk PTN dan diterima di jurusan Matematika. Klien berulangkali mengevaluasi dirinya sebagai seseorang yang tidak berkompeten atas kegagalan dan keterlambatannya dalam menyelesaikan pendidikan S1 Matematika.

Klien menerapkan pemikiran yang keliru atas apa yang telah terjadi pada dirinya, yaitu dengan terpaku pada hal yang negatif dan mengabaikan hal-hal yang positif (Ellis \& Robb, 1994). Klien berusaha menuntut dirinya sehingga dapat menyelaraskan diri dengan keyakinanya yang dia percayai sehingga klien mengikuti pengajian-pengajian. Pengajian dilihat sebagai pelarian akan masalah akademiknya untuk mendapatkan pengakuan dirinya masih berkompeten untuk dianggap berharga. Melalui pengajian, klien mendapatkan suatu doa dimana klien sangat bergantung pada doa tersebut, bahwa dengan berdoa dapat membantunya dalam menyelesaikan masalah. Sehingga klien fokus berdoa dan abai pada kewajibannya untuk segera menyelesaikan skripsi.

Dinamika terbentuknya gangguan skizofrenia pada klien yang dilihat dari faktor penyebabnya dapat dijelaskan melalui teori ABC dari Ellis (Corey, 2009). A (antecedent event) atau kejadian pencetus, B (believe) atau keyakinan, dan $\mathrm{C}$ (consequence) atau konsekuensi sebagai akibat atau reaksi individu. Klien berulangkali mengembangkan keyakinan irasional, yang menyebabkan terhambatnya pencapaian atas tujuan-tujuan klien. Ketika berpikir dan berperilaku irasional dapat berakibat menjadi seorang individu yang tidak efektif (Corey, 2009).

Dapat dijabarkan dengan kegagalan klien masuk PTN pada jurusan yang diinginkannya adalah sebagai kejadian pencetus. Kejadian tersebut dimaknai bahwa dirinya kurang berkompeten sehingga memunculkan keyakinan bahwa untuk dianggap berharga dirinya harus berkompeten sehingga menimbulkan konsekuensi menarik diri dan pemberian label negatif pada dirinya. Klien memiliki daya toleransi terhadap suatu distress yang rendah, dimana klien tidak mampu menghadapi suatu masalah dan lebih memilih untuk berdiam diri dan pasif. Selain itu klien juga memiliki distorsi kognitif yang berupa untuk dianggap berharga maka harus benar-benar kompeten, adekuat, dan berprestasi (Erford, 2011) yang dikembangkan oleh klien sejak duduk di bangku sekolah dasar.

Didukung dengan tidak dimilikinya kemampuan mengatasi masalah yang baik, klien tidak mampu mengatasi permasalahan dengan memberikan respon positif. Kecenderung menghindar dengan tidur, menyalahkan diri sendiri dengan memberikan label negatif pada diri dan berdoa dengan mengamalkan dzikir. Sehingga membuat permasalahan klien semakin bertumpuk, pada akhirnya sampai pada ambang batas kemampuan untuk menerima dan menjadi sesuatu yang patologis. Hal ini nampak dari hasi tes TAT dimana terdapat kebutuhan pasif yang dominan. Tidak terdapat suatu pemecahan masalah pada setiap kartu serta didominasi oleh perasaan-perasaan negatif seperti putus asa, sedih, merasa frustasi dan ditolak oleh lingkungan.

Pengajuan judul skripsi yang telah berulangkali dan penolakan dari dosen pembimbing serta tuntutan dari orangtua untuk segera menyelesaikan pendidikan membuat klien semakin mengembangkan keyakinan irasionalnya. Dengan ciri kepribadian premorbid cenderung kaku dan adanya kebutuhan pasivity serta kesulitan dalam mengekspresikan diri membuat klien semakin rentan ketika mendapatkan tekanan atau sedang menghadapi masalah. Klien mengabaikan hal-hal positif mengenai potensi dirinya, terpaku pada hal negatif dan terlalu cepat dalam menggeneralisasi masalah (Corey, 2009) 
selalu dilakukannya berulangkali ditambah dengan coping yang tidak sesuai hingga akhirnya menjadi sesuatu yang patologis. Hal tersebut menjadi pencetus sehingga klien didiagnosa mengalami ganggauan jiwa dan mendapatkan perawatan untuk pertama kalinya yang muncul secara akut dengan adanya halusinasi auditorik.

Pada perawatan ketiga, adalah sesaat setelah klien memutuskan keluar dari pekerjaannya sebagai guru matematika SMP di Malang. Dipicu oleh hasil nilai TOEFL klien yang lebih tinggi dibandingkan nilai guru Bahasa Inggris di sekolah tersebut, klien berpikir bahwa guru-guru bersekongkol untuk mengeluarkan dirinya dari sekolah tersebut. Adanya kecenderungan dalam diri klien bahwa dirinya ditolak baik oleh individu lain ataupun lingkungannya serta merasa tidak memiliki teman yang mampu mendukung cita-citanya membuat klien semakin mengembangkan pemikiranpemikiran yang irasional. Pada waktu yang bersamaan kakak klien menanyakan pekerjaan suami klien, hal tersebut memunculkan pemikiran bahwa kakak klien tidak menyetujui dirinya menikah dengan $\mathrm{TN}$ yang saat itu telah menjadi suaminya.

Pola yang serupa terjadi pada kekambuhan berikutnya, dimana adanya ketidakpuasaan akan diri klien, lingkungan dan sekitarnya. Seperti saat perawatan klien yang keempat, adanya keyakinan grandiose karena berpikir bahwa dirinya begitu istimewa sehingga kondisinya harus nyaman dan memuaskan bahagia. Hal tersebut nampak saat klien menyatakan standar pendidikan di Pasuruan sangat berbeda, dibawah harapan klien, yaitu pembelajaran matematika harus sesuai dengan standar yang benar, dan ketika klien melemparkan ide murid harus dapat menanggapinya dengan baik. Namun yang terjadi adalah sebaliknya, dimana para murid tidak mampu menganggapi ide yang dileparkan oleh klien dengan baik.

Klien merasa ada konspirasi diantara murid tersebut yang berusaha menjatuhkan dirinya sebagai seorang guru matematika yang berprestasi. Klien mengembangkan distorsi kognitif bahwa klien merasa harus dicintai atau disetujui oleh hampir semua orang yang memiliki hubungan dengannya (Corey, 2009), termasuk para murid yang harus mampu menimpali setiap ide yang disampaikan olehnya.

Pada perawatan yang kelima, terdapat suatu kejadian pencetus dimana tetangga klien membicarakan mengenai mantan istri dari suami klien. Klien merasa bahwa suaminya berselingkuh, ditambah dengan adanya kejadian Ibu klien mengunjungi klien di Pasuruan dan bermaksud untuk mengajak klien kembali pulang ke Malang. Ditambah klien yang masih meyakini bahwa lingkungan tempat tinggalnya menolak dirinya sejak klien mengundurkan diri dari sekolah. Hal tersebut memperkuat keyakinan klien bahwa suaminya tidak mencintainya lagi, sampai-sampai sang Ibu ingin membawa klien pulang ke Malang. Kejadian tersebut menimbulkan konsekuensi klien mencurigai suaminya, marah terhadap suami, tidak lagi mengerjakan pekerjaan rumah dan semakin menarik diri dari lingkungan. Adanya tuntutan baik pada diri klien, oranglain maupun lingkungan yang pada keadaan tertentu merujuk pada keharusan sebagaimana hukum alam (Froggatt, 2005).

Dari pengalaman hidup klien, terlihat bahwa klien memiliki keyakinan yang tidak rasional sejak lama yang menyebabkan klien menjadi pribadi yang terlalu menuntut dan menilai diri secara negatif. Klien tidak mampu berpikir secara jelas dan bergantung pada orang lain. Pengalaman masa lalu memberikan pengaruh yang sangat kuat terhadap kehidupan individu dan menentukan tingkah lakunya pada saat ini. Karena saat ini klien masih dipenuhi dengan keyakinan yang tidak rasional sehingga perilaku patologis tetap muncul.

Pola pemikiran klien yang sudah irasional, membuat semuanya menjadi irasional, karena pemikiran irasional pertama yang tidak tertangani dengan baik, mengakibatkan klien terus menerus berpikir secara sempit yang semakin lama semakin memburuk karena masalah utama belum terselesaikan, sehingga pada kejadian-kejadian kecil dalam kehidupan sehari-hari dapat menjadi sesuatu yang besar. Sehingga intervensi berupa pendekatan kognitif dengan teknik REBT dianggap cocok dan dengan tujuan utama dari psikoterapi ini adalah memperbaiki dan merubah sikap, persepsi, cara berfikir, keyakinan serta pandangan klien yang irasional dan tidak logis menjadi rasional dan logis agar klien dapat mengembangkan diri (Corey, 2009).

\section{Diagnosis dan Prognosis}

Hasil diagnosis klien telah memenuhi kriteria diagnostik DSM-5 untuk gangguan skizofrenia (295.90) dengan permasalahan permasalahan rendahnya penerimaan diri yang disebabkan oleh irrational belief. Prognosis baik karena adanya dukungan keluarga (suami) untuk pulih, tidak adanya faktor keturunan, faktor pencetus jelas dan klien telah mendapatkan pengobatan sejak awal gejala muncul.

\section{Intervensi}

REBT digunakan karena permasalahan dasar klien ialah rendahnya penerimaan terhadap diri, orang lain dan lingkungan yang disebabkan oleh irrational belief. Dengan ciri kepribadian premorbid cenderung kaku, suka berkontemplasi dan adanya kebutuhan pasivity membuat klien semakin rentan ketika mendapatkan tekanan atau sedang menghadapi masalah. Rendahnya penerimaan diri timbul dari adanya demandingness dimana segala sesuatu adalah harus, seperti berpikir bahwa dirinya begitu istimewa sehingga kondisinya harus nyaman dan memuaskan. Hal tersebut nampak saat klien menyatakan standart pendidikan di Pasuruan sangat berbeda, dibawah harapan klien. "pembelajaran matematika harus sesuai dengan standart yang benar, dan ketika saya melemparkan ide murid harus dapat menanggapinya). Selain itu klien juga berpikiran bahwa dirinya harus cerdas dan berkompeten untuk dapat diterima oleh orang lain dan 
harus disetujui, dihormati dan dicintai oleh orang lain. REBT merubah respon tidak sehat menjadi respon yang lebih sehat dengan menantangnya akan memungkinkan keterlibatan lebih besar dalam kehidupan dan pencapaian tujuan pribadi sehingga akan meningkatkan kebahagiaan (Harrington, 2011). Selain itu pemilihan intervensi REBT ini juga didasari karena kemampuan kognitif klien yang baik.

Sebelum penerapan REBT, diberikan psikoedukasi kepada keluarga. Psikoedukasi berupa penjelasan tentang skizofrenia untuk meningkatkan kepedulian kepada klien dan berkomitmen memberikan dukungan dalam hal perawatan pasca keluar dari rumah sakit. Hal ini diperlukan untuk mendukung hasil intervensi mengingat REBT pada pasien skizofrenia tidak dapat dilakukan sendiri sehingga membutuhkan dukungan orang lain untuk dapat terus mempertahankan pemikiran baru ataupun mematahkan irrational belief serta pendampingan saat klien mencoba menerapkan suatu perilaku baru yang lebih adaptif. Informasi yang diberikan kepada keluarga antara lain tentang skizofrenia secara umum, pentingnya konsumsi obat secara teratur dan kerjasama keluarga untuk mendukung pasien dalam menjaga pola pikir dan penerapan perilaku adaptif agar dapat menerima diri dengan lebih baik. REBT diterapkan melalui lima sesi yang dilakukan dengan waktu 60-90 menit pada setiap sesinya.

Sesi I: Membangun raport. Membuat kesepakatan tentang rencana terapi sekaligus waktu pelaksanaannya. Klien memahami tentang terapi yang akan dilaksanakan dan menyatakan kesediaannya.

Sesi II: Identifikasi masalah, orang dan situasi . Mengidentifikasi irrational belief klien dengan menggunakan tabel core belief dari Ellis. Klien memberikan respon sesuai dengan instruksi. Diketahui beberapa irrational belief klien berupa, harus dicintai atau disetujui oleh hampir semua orang yang memiliki hubungan dengan klien dan klien harus benar-benar kompeten, adekuat dan berprestasi agar dianggap berharga, dengan tipe demandingness. Pada sesi ini juga dijelaskan mengenai proses $\mathrm{ABC}$, sehingga klien memahami tentang proses $\mathrm{ABC}$ yang terjadi pada dirinya. Dimana dengan mengidentivikasi B (belief) yang menyebabkan munculnya suatu emosi dan konsekuensi perilaku pada individu (MacLare et al., 2016).

Sesi III: Implementasi REBT I Menggunakan teknik irational emotive imagery, teknik ini dirancang untuk menampilkan kehidupan seseorang, dan dunia pada umumnya, berlanjut setelah peristiwa yang ditakuti atau tidak diinginkan telah datang dan pergi. Dengan meminta klien untuk memvisualisasikan kejadian yang tidak diinginkan yang pernah dialaminya.

Klien diminta untuk memvisualisasikan suatu kejadian pengaktif yang tidak menyenangkan, dengan membayangkan suatu kejadian dengan benar-benar detail dan jelas. Klien dapat megemukakan pengalaman emosi-emosi negatif yang dirasakannya kembali saat melakukan visualisasi dan memberikan waktu pada klien untuk menghadapi emosi tersebut. Setelah itu, klien diminta mengubah emosi negatif menjadi emosi positif (negative imagery-positive imagery) dengan menggunakan proses ABCyang telah disampaikan kepada klien, dan digunakan pula forcefull disputing untuk mematahkan irrational believe dan menghasilkan pemikiran serta emosi positif yang baru.

Hasil dari sesi ke tiga adalah klien membayangkan suatu kejadian saat memutuskan mengundurkan diri dari SMP di Prigen, klien merasa sepanjang hidupnya banyak sekali merasakan unfairplay dan pembunuhan karakter berkali-kali. Termasuk kekecewaannya pada murid yang tidak merespon sebagaimana harusnya. Terapis melakukan pembantahan dan klien mulai menyadari dengan mengatakan bahwa tidak semua hal harus berjalan sesuai dengan yang direncanakan dan harus sesuai dengan ketetapan secara umum. Terapis memberi pekerjaan rumah agar klien mulai aktif dalam kegiatan sosial di kampung (seperti pengajian).

Sesi IV: Implementasi REBT // Sama seperti pada sesi ke tiga, namun dengan menggunakan suatu kejadian yang berbeda. Klien menyampaikan telah mencoba hadir dalam tahlilan aqiqoh dengan ditemani adik ipar, dan benar irrational belief klien tidak terbukti sehingga klien termotivasi untuk mencoba hal lainnya. Klien mendapatkan pemahaman baru bahwa untuk dihargai tidak selalu harus berkompeten dan berprestasi. Menjadi seseorang yang jujur dan ramah juga akan mendatangkan penghargaan dari orang lain. Terapis memberikan pekerjaan rumah untuk melakukan hal yang sama dan mendiskusikannya dengan suami klien (suami klien turut serta dalam setiap sesi terapi) dan mencoba aktif kembali dalam kegiatan sosial kemayarakatan di lingkungan tempat tinggal klien.

Sesi V: Evaluasi dan terminasi. Saat evalusi klien menyampaikan kepuasannya selama sesi terapi karena merasa ada yang mendengarkan dirinya dan mampu mengkonfrontir dirinya sehingga dapat melihat suatu kejadian dari sudut pandang yang berbeda dan menghasilkan alternatif pikiran lainnya sehingga menyadari bahwa seorang individu tidak harus pandai, berkompeten dan selalu disetujui oleh orang lain.

Sesi VI: Follow up. Follow up dilakukan dua minggu setelah sesi terapi berakhir. Saat dilakukan follow up, klien menunjukkan 'bentelan' yang akan dibuat menjadi tas. Klien mengikuti kegiatan membuat kerajinan tangan bersama ibu-ibu dasawisma. Hal tersebut menunjukkan klien telah mulai mengikuti kegiatan sosial/ berinteraksi dengan lingkungan sekitarnya. 


\section{Hasil dan Pembahasan}

\section{Hasil}

Berdasarkan hasil intervensi didapatkan adanya perubahan dalam diri klien yang merujuk pada keberhasilan intervensi. Diantaranya klien sudah mampu memandang suatu permasalahan dari sudut pandang yang lain, sehingga memunculkan berberapa alternatif pemikiran lain. Klien tidak lagi terpaku pada satu pemikiran yang didasari oleh irrational belief. Dari hasil pemikiran-pemikiran baru klien tersebut, klien lebih dapat menerima diri, orang lain dan lingkungan dilihat dari klien yang telah menyadari bahwa tidak semua hal harus berjalan sebagaimana yang diharapkan, dan harus sesuai dengan sebagaimana hukum alam pada umumnya dan menyetujui dirinya.

Dalam aspek perilaku, terdapat perbedaan antara sebelum dilakukan intervensi dan setelah dilakukan intervensi. Sebelum dilakukan intervensi klien cenderung menarik diri dari lingkungan dengan tidak mau mengikuti kegiatan sosial di lingkungan rumah dengan alasan orangorang di lingkungan klien menolaknya. Namun setelah intervensi klien kembali ikut pengajian di kampung, bahkan mulai aktif membuat kerajinan mbenthel bersama warga di sekitar rumah klien.

\section{Pembahasan}

Tujuan dari REBT adalah agar klien mampu mengidentifikasi pemikiran irasional, perasaan dan perilaku dengan benar serta mampu mengaplikasikan REBT pada kejadian lainnya sesuai dengan kebutuhan (Ellis \& Robb, 1994). Sebelum dilakukan intervensi terhadap klien, sebelumnya dilakukan pula psikoedukasi terhadap keluarga. Peran keluarga selama proses intervensi menjadi hal yang berpengaruh terhadap keberhasilan terapi, karena keluarga merupakan sistem pendukung utama yang memiliki peran penting dalam melakukan pendampingan klien (PitschelWaltz, 2004).

Psikoedukasi merupakan suatu metode yang berguna untuk memberikan dukungan kepada orang dengan gangguan mental dan keluarga mereka. Pengetahuan yang disampaikan dengan mempertimbangkan keadaan psikologis mereka sehingga memungkinkan mereka untuk mengatasi masalah yang disebabkan oleh gangguan mental (Shiraishi, 2014). Bukti terbaru telah menunjukkan bahwa psikoedukasi untuk keluarga dan pasien skizofrenia dapat mengurangi frekuensi kekambuhan, penerimaan kembali dan meningkatkan kepatuhan pengobatan (Xia, 2011).

Teknik REBT yang diberikan kepada klien memberikan hasil positif terhadap meningkatnya penerimaan klien terhadap diri, orang lain yang diiringi dengan peningkatan perilaku sosial klien. Teknik REBT yang diberikan pada klien berupa membayangkan ulang kejadian tidak menyenangkan yang pernah dialami klien atau yang biasa dikenal dengan teknik rational emotive imagery, terapis membantu untuk menghasilkan pemikiran yang lebih rasional terkait permasalahan tersebut dengan melakukan forcefull disputing, hingga akhirnya klien mendapatkan pemahaman baru dan menghasilkan emosi positif serta diharapkan dapat melakukannya sendiri. Disputing merupakan pendekatan aktif untuk membantu klien mengevaluasi bantuan dan efikasi dari irational belief dan sistem keyakinannya, sehingga dapat menghasilkan suatu pemikiran baru dan solusi baru dalam dirinya (MacLare et al., 2016). Pemikiran seseorang sangat berpengaruh pada perilaku yang akan dihasilkan (Alwisol, 2009). Sehingga dengan adanya perubahan kognitif diikuti pula dengan perubahan perilaku pada klien.

REBT telah terbukti mampu meningkatkan toleransi distres, frustasi ataupun ketidaknyamanan (Rodman, 2009) yang merupakan suatu fakta yang tidak dapat dihindarkan, dengan menolaknya akan menambah suatu kesengsaraan. REBT merubah respon tidak sehat menjadi respon yang lebih sehat dengan menantangnya akan memungkinkan keterlibatan lebih besar dalam kehidupan dan pencapaian tujuan pribadi sehingga akan meningkatkan kebahagiaan (Harrington, 2011).

Selain itu, intervensi yang diberikan juga terbukti mampu meningkatkan unconditional self acceptance atau yang dalam kasus ini disebutkan sebagai penerimaan diri. Klien sebelumnya berpikiran bahwa dirinya harus berprestasi, berkompeten dan selalu tepat dalam melakukan apapun dalam hidupnya. Bahwa segala sesuatunya berlaku suatu hukum keharusan serta klien juga berkeyakinan bahwa dirinya harus selalu dicintai oleh orang lain dan pendapatnya harus disetujui. Hal tersebut membuat klien mejadi pribadi yang penuntut termasuk dalam menerima dirinya sendiri. setelah dilakukan intervensi, klien memiliki pemikiran baru, bahwa segalanya tidak harus absolut dan mulai memiliki beberapa pemikiran baru yang berujung pada penerimaan diri bahwa seseorang tidak harus selalu sempurna dan berprestasi serta mungkin orang lain memiliki pendapat yang berbeda sehingga tidak harus selalu setuju.

Penerimaan diri didefinisikan sebagai kemampuan individu untuk mempertahankan perasaan positif secara utuh di tengah segala kekurangan dan/ atau kegagalan (Chamberlain \& Haaga, 2001). Sehingga, penerimaan diri mencerminkan kemampuan individu untuk merangkum kekuatan dan kelemahan mereka serta sering berfungsi sebagai indikasi kepuasan pribadi dan kebahagiaan (Chamberlain \& Haaga, 2001). Albert Ellis menurunkan konsep penerimaan diri tanpa syarat dari Rational Emotive Behavior Therapy (REBT), di mana seorang individu bekerja untuk sepenuhnya menerima dirinya sendiri, orang lain, dan kehidupan (Dryden \& Neenan, 2004),

Ellis \& Robb (1994) menyatakan bahwa seorang individu dengan penerimaan diri tanpa syarat sebagai seseorang yang telah sepenuhnya dan tanpa syarat menerima dirinya sendiri apakah dia berperilaku cerdas, benar atau kompeten, dan apakah orang lain menyetujui, menghormati dan mencintainya. Untuk memperjelas, penerimaan diri tanpa syarat tidak berarti bahwa seseorang mengabaikan kelemahan mereka, melainkan dengan 
melepaskan "kinerja" dari harga diri dan apa yang orang lain pikirkan (terlepas dari hasil positif atau negatif (DiGiuseppe, 2014). Selain itu, memungkinkan individu untuk menetapkan dan mengejar standar tujuan tinggi tanpa menghadapi perasaan gagal atau berperilaku dengan cara disfungsional karena harga diri tidak bergantung pada hasil kinerja tunggal (Dryden \& Neenan, 2004).

Unconditional Self Acceptance (USA) atau yang dalam kasus ini disebutkan dengan penerimaan diri, adalah berdasarkan definisi dan kriteria USA dari Ellis tanpa menggunakan skala ataupun alat ukur lainnya, sehingga menjadi keterbatasan dalam intervensi ini. Keberhasilan dari intervensi yang berupa peningkatan penerimaan diri adalah dilihat dari kognitif dan perilaku yang ditampilkan oleh klien dimana klien mulai berpikir bahwa segala sesuatu tidak harus berjalan sesuai dengan yang direncanakan dan sesuai dengan ketetapan universal. Serta perilaku klien yang mulai mau kembali beraktifitas dan berkumpul dengan tetangga sekitar.

\section{Kesimpulan}

REBT berperan dalam membantu klien skizofrenia untuk memiliki penerimaan diri, orang lain dan lingkungannya dengan lebih baik sehingga meningkatkan keberfungsian sosialnya. Peran keluarga dalam memberikan dukungan dan keterlibatannya dalam proses intervensi menjadi hal penting yang mendukung keberhasilan intervensi. Selain itu, kemauan klien untuk berubah dan penetapan target secara realistis menjadi hal penting yang dalam pencapaian klien. Melalui penerapan REBT, klien diharapkan dapat menjalani aktivitas sehari-hari secara lebih produktif dan mengurangi kerentanannya terhadap relapse. Intervensi ini tidak mengesampingkan konsumsi obat dan pemeriksaan medis yang tetap harus dilakukan oleh klien secara teratur.

\section{Referensi}

American Psychiatric Association. (2013). Diagnostic and statistial manual (5th ed.) American Psychiatric Publishing.

Alford, B. A., \& Beck, A. T. (1994). Cognitive therapy of delusional beliefs. Behaviour Research and Therapy, 32(3), 369-380. https://doi.org/10.1016/0005-7967(94)90134-1

Alwisol. (2009). Psikologi kepribadian. UMM Press.

Corey, G. (2009). Teori dan praktik konseling dan psikoterapi. PT. Refika Aditama

Cunningham, R. \& Turner, M. J. (2016). Using rational emotive behavior therapy (REBT) with mixed martial arts (MMA) athletes to reduce irrational beliefs and increase unconditional self-acceptance. Journal of Rational-Emotive \& Cognitive-Behaviour Therapy, 34(4), 289-309. https://doi. org/e/10.1007/s10942-016-0240-4

Chamberlain, J. M., \& Haaga, D. A. F. (2001). Unconditional self-acceptance and psychological health. Journal of Rational-Emotive and Cognitive-Behavior Therapy, 19, 163-176. https://doi.org/10.21465/2016-SP-191-06
Davison, G.C., Neale, J.M., \& Hindman, D. (2000). Study guide abnormal psychology (Eight Edition). John Wiley \& Sons.

DiGiuseppe, R. A., Doyle, K. A., Dryden, W., \& Backx, W. (2014). A practitioner's guide to rational emotive behavior therapy ( $3 r d$ ed.). Oxford University Press.

Dryden, W., \& Neenan, M. (2004). The rational emotive behavioral approach to therapeutic change. Sage Publishing.

Ellis, A., \& Robb, H. (1994). Acceptance in rational emotive therapy. In S. C. Hayes, N. S. Jacobson,V. M. Follette, \& M. J. Dougher (Eds.),Acceptance and change: Content and context inpsychotherapy. Context Press

Erford, B. T. (2011). 40 Teknik yang harus diketahui setiap konselor. Pustaka Pelajar

Froggatt, Wayne. (2005). A Brief Introduction to Rational Emotive Behaviour Therapy (Third edition).

Harrington, Neil. (2011). Frustration intolerance: therapy issues and strategies. Journal of Rational-Emotive \& CognitiveBehaviour Therapy, 29(2), 4-16. https://doi.org/10.1007/ s10942-011-0126-4

Halgin, R.P., \& Withbourne, S.K. (2011). Psikologi abnormal: Perspektif klinis pada gangguan psikologis. Salemba Humanika

MacLaren, C., Doyle, K. A., DiGiuseppe, R. (2016). Rational Emotive Behaviour Therapy (REBT): theory and practice. SAGE Publication Inc.

Pitschel-Waltz, G., Leucht, S., Bauml, J., Kissling, W., Engel. R.R. (2004). The effectof family interventions on relapse and rehospitalization in schizophrenia: a meta- analysis. Journal of Lifelong Learning in Psychiatry, 2(1), 78 - 94. https: //doi.org/10.1176/foc.2.1.78

Rodman, A. A., Daughters, S. B., Leujuez, C. W. (2009). Distress tolerance and rational-emotive behavior therapy: a new role for behavioral analogue tasks. Journal of Rational-Emotive \& Cognitive-Behaviour Therapy, 27(2), 97-120. https://doi. org/10.1007/s10942-009-0090-4

Sakakibara, Eisuke. (2016). Irrationality and pathology of beliefs. Neuriethics, 9(2), 147 - 157. https://doi.org/10.1007/s12152016-9256-9

Shiraishi, N., Watanabe, N., Kinoshita, Y., Kaneko, A., Yoshida, S., Furukawa, T. A., Akechi, T. et al., (2014). Brief psychoeducation for schizophrenia primarily intended to change the cognition of auditory hallucinations an exploratory study. The Journal of Nervous and Mental Disease, 202(1), 35 - 39. https://doi.org/10.1097/NMD. 0000000000000064

Thome, Johannes. (2015). Integrating pharmachotherapy and psychotherapy. Journal of a Neural Transmission, Vol. 122 Supplement 1, 1-2. https://doi.org/10.1007/s00702-015-141

Xia J, Merinder LB, Belgamwar MR (2011) Psychoeducation for schizophrenia. Cochrane Database Syst Rev. PMID: 21678337 PMCID: PMC4170907. https://doi.org/10.1002/ 14651858.CD002831.pub2 